\title{
Financial Report-form Analysis of Guizhou Mao-tai Group Limited Company Nearly 5 years
}

\author{
Mei Zhang, Huan Liu \\ School of Informatics, Guizhou University of Finance and Economics, Guiyang, China \\ E-mail: zm_gy@sina.com,942833674@qq.com
}

\begin{abstract}
Financial statement analysis of the data summary, comparison, analysis, the disclosure of the consolidated financial statements, and can objectively evaluate the financial situation of enterprises to understand the company's operating results. Mao-tai Group 2009-2013 financial report as the basis, combined with financial management theory and their own situation, to analyze the organic combination of the financial statements of related indicators. Through the five-year longitudinal analysis of financial data and research, trying to find out the business in the financial management and decision-making in the problems and found that company's strengths and weaknesses, providing help for the corresponding reference Mao-tai Group management and investment decisions, and help set investment and interested parties have relevant financial condition, cash flows and results of operations of Mao-tai. Conducive to economic management departments to understand the health of the economy Mao-tai Group, ensure the stable development of the national economy, which has a certain reference value for the sound development of Guizhou Mao-tai Group AG.
\end{abstract}

Keywords-Guizhou Mao-tai, Financial Report-form analysis, financial management; financial ratio analysis

\section{SOLVENCY ANALYSIS}

Solvency analysis is based on the balance sheet to reflect the data, the ability to reflect in a given period to repay debt, including long-term and short-term [1, 2]. Long-term solvency indicators have asset-liability ratio, equity ratio, equity multiplier, etc., see equation (1) - (3). They are assets and liabilities of the enterprise computing, especially the ability to obtain profits reflect the capital structure and business. Under normal circumstances, an enterprise for the debt alone will not sell assets to achieve, but with their own business area achieved operating profit therefrom, so when he says that long-term solvency is mainly dependent on the profitability, this is just to analyze the safety claims.

$$
\begin{gathered}
\text { Assets and liabilities }=\frac{\text { Total liabilities }}{\text { Total assets }} * 100 \% \\
\text { property right ratio }=\frac{\text { Total liabilities }}{\text { Thetotal owners'equity }} * 100 \% \\
\text { Rights and interests multiplier }=\frac{\text { Total assets }}{\text { Thetotal owners'equity }} * 100 \%
\end{gathered}
$$

According to related literature, calculate 2009--2013 Long - term solvency data in TABLE 1.

TABLE I. MAO-TAI GROUP'S LONG-TERM SOLVENCY OF THE PAST FIVE YEARS TABLE Unit (\%)

\begin{tabular}{|l|c|c|c|c|c|}
\hline & $\mathbf{2 0 0 9}$ & $\mathbf{2 0 1 0}$ & $\mathbf{2 0 1 1}$ & $\mathbf{2 0 1 2}$ & $\mathbf{2 0 1 3}$ \\
\hline Asset liability ratio & 0.26 & 0.28 & 0.27 & 0.21 & 0.2 \\
\hline Property right ratio & 0.26 & 0.27 & 0.37 & 0.38 & 0.35 \\
\hline Rights and interests multiplier & 1.35 & 1.39 & 1.37 & 1.27 & 1.25 \\
\hline
\end{tabular}




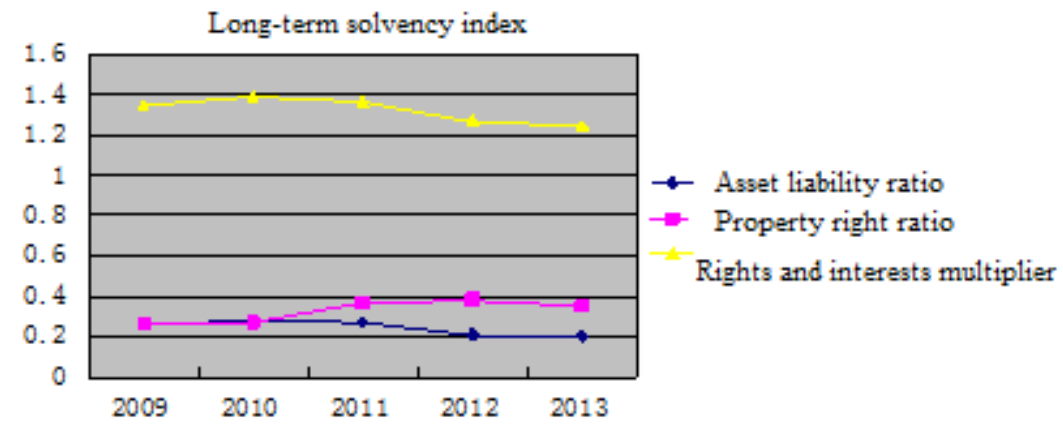

Figure 1 Guizhou Mao-tai 2009--2013 Long - term solvency index trend

From Figure 1,we can know, Mao-tai Group's asset-liability ratio from 2009 to 2013 in five years remained at a relatively stable state, in addition to 09 to 11 years more than two years in addition to 0.25 , followed by two years the year are relatively stable and at about 0.20 , and five years basically showing a downward trend, suggesting that the balance increased safety in the long term, this trend is to ensure the company insolvent stable, long-term solvency is relatively stable but also improve the stability of the business confidence of investors and creditors for the company's normal operation will also provide a stable environment, can bring greater benefits for the company, but for shareholders, debt ratio can be more hope General Assembly to bring their own greater profit, so it is relatively contradictory. Overall lower asset-liability ratio can also reduce the risk of long-term debt repayment of corporate finance, which will improve the profitability of enterprises.

Solvency as well as short-term solvency index, which includes flow rate, quick ratio, etc., see equation (4)-(5)

$$
\text { Flow } \quad \text { rate }=\frac{\text { Current assets }}{\text { Current liabilities }} * 100 \%
$$

$$
\text { Quick ratio }=\frac{\text { Quick assets }}{\text { Currentliabilities }} * 100 \%=\frac{\text { Current assets }- \text { stock }}{\text { Current liabilities }} * 100 \%
$$

According to related literature, calculate 2009-2013

Short - term solvency data in TABLE 2.

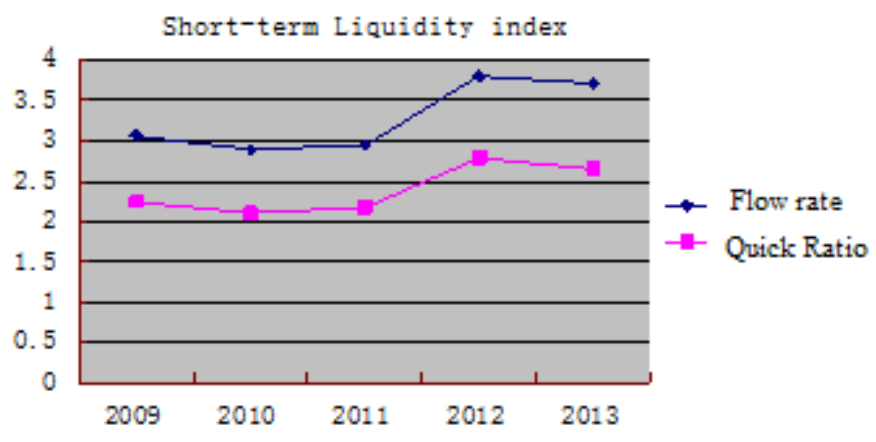

Figure 2 Mao-tai 2009 - 2013 short-term liquidity tren

TABLE II. MOUTAI NEARLY 5 YEARS OF SHORT-TERM SOLVENCY TABLE INIT $(\%)$

\begin{tabular}{|l|l|l|l|l|l|}
\hline & $\mathbf{2 0 0 9}$ & $\mathbf{2 0 1 0}$ & $\mathbf{2 0 1 1}$ & $\mathbf{2 0 1 2}$ & $\mathbf{2 0 1 3}$ \\
\hline Flow rate & 3.06 & 2.89 & 2.94 & 3.8 & 3.71 \\
\hline Quick Ratio & 2.24 & 2.1 & 2.18 & 2.79 & 2.66 \\
\hline
\end{tabular}


Derived from Figure 2, Mao-tai liquidity ratio from 09 to 11 years is relatively stable, since there is a growing trend followed by stable, see did not reach a 2:1 optimum level, indicating that the company the short-term solvency is strong, the interests of creditors more secure, look quick ratio and current ratio is the same as the increase or decrease in a situation, explained the company's idle funds is more, most of the cash is the presence of the bank, resulting in increased costs do not take advantage of opportunities from the points, so Mao-tai should be careful to adjust the capital structure, the flow of funds for the enterprise more efficient and profitable.

\section{PROFITABILITY ANALYSIS}

Profitability typically includes operating margin, the profit margin and return on assets, the ideal state of corporate earnings generally need to include the following aspects: first, with good profitability; the second is the need for a more robust cash support; the third is to have a good potential for development. Profitability reflects all aspects of the relationship between the core businesses, but also on profit margins in-depth analysis of the key [3-5], a company can do in order to continue operating in the true sense, the only long-term profitability. So for investors or creditors, should reflect corporate profitability related indicators to be valued. Therefore, corporate profitability analysis, can be found appearing on management issues, and together make a fundamental judgment in making business decisions and other financial indicators, the following is a formula for calculating the three indicators (6) - (8).

$$
\text { Operating profit ratio }=\frac{\text { Business profit }}{\text { Operating income }} * 100 \%
$$

$$
\text { Net sales rate }=\frac{\text { Net profit }}{\text { Sales revenue }} * 100 \%
$$

$$
\text { Asset returns } \text { ratio }=\frac{\text { Total profit before taxinterest }}{\text { Averagetotal assets }} * 100 \%
$$

According to related literature, calculate 2009--2013 earnings capacity index results in Table 3

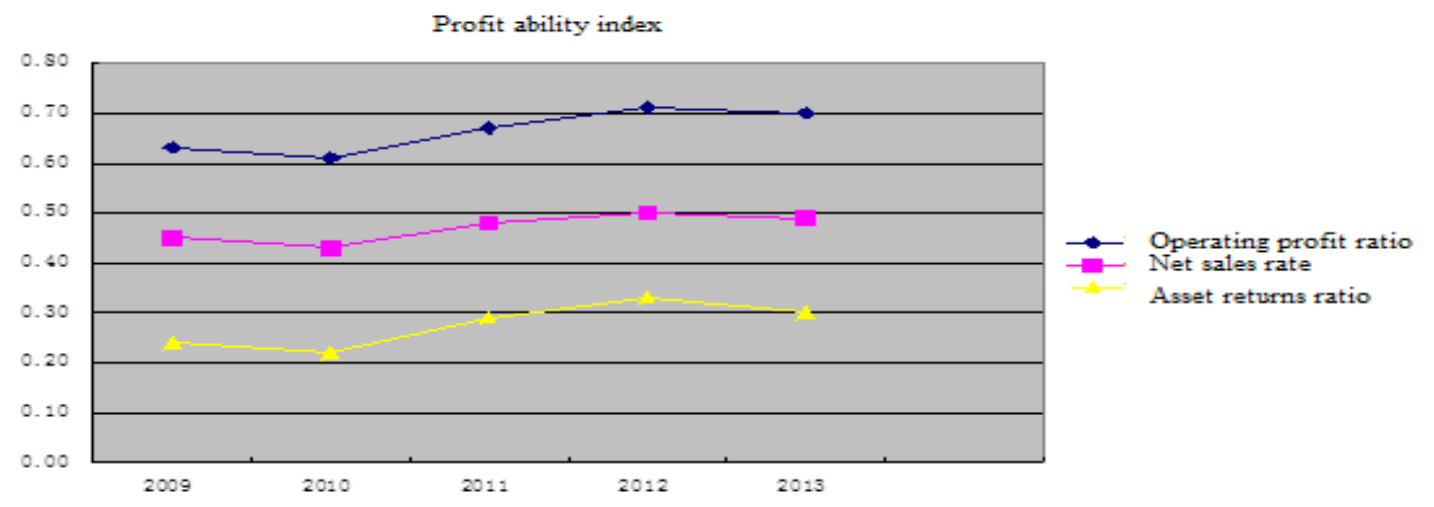

Figure 3 2009-2013 Guizhou Mao-tai profitability trends related indicators

TABLE III. MOUTAI NEARLY 5 YEARS PROFITABILITY TABLE UNIT（\%)

\begin{tabular}{|l|l|l|l|l|l|}
\hline & $\mathbf{2 0 0 9}$ & $\mathbf{2 0 1 0}$ & $\mathbf{2 0 1 1}$ & $\mathbf{2 0 1 2}$ & $\mathbf{2 0 1 3}$ \\
\hline Operating profit ratio & 0.63 & 0.61 & 0.67 & 0.71 & 0.70 \\
\hline Net sales rate & 0.45 & 0.43 & 0.48 & 0.50 & 0.49 \\
\hline Asset returns ratio & 0.24 & 0.22 & 0.29 & 0.33 & 0.30 \\
\hline
\end{tabular}


By Figure 3, the operating margin from 2009 to 2013 generally show steady growth trend, although the decline in 2010 , when the $(0.63-0.61)=0.02$ compared with 2009 , but after three years in the minor increases in a relatively stable state, gradually increase in operating profit, so Mao-tai product sales, strong corporate profitability. Sales margin is the percentage of net profit and net sales of enterprises, and from 2009 to 2013, the sales margin growth in a small range of relatively stable, but there are 2010 decline phenomenon. Description profit under sales revenue this year to get a little less. Finally, look at return on assets, it refers to the comprehensive utilization of indicators of corporate assets, the past five years, the data fluctuate in 0.20-0.30, indicating still relatively stable, although businesses to invest in the general level of output, but the development of enterprises to effectively operating assets make Mao-tai the past five years the profitability is still relatively strong.

Relations between these three indicators profitability, expenses increased during the Mao-tai Group trend to some extent beyond the sales profit rate, and Mao-tai Group did not get preferential tax policy. And liquor manufacturing industries in recent years gradually increased raw material prices, so there is no substantial increase resulting Mao-tai appear in return on assets.

If you want to Mao-tai improve profitability is relatively good, should be appropriate to reduce some of the costs, strict cost control and management system for raw materials and other measures to reduce the adverse effects of the bidding suppliers, to maintain its level of profitability continues to increase. To maintain its profitability level continues to increase.

ROE is the percentage of net profit after tax and owners' equity between, which reflects the size ofcorporate profits, it is financial statement analysis in a highly comprehensive analysis of indicators, which is calculated, see equation (9). Mao-tai net assets in recent years are shown in Figure 4 below.

$$
R O E=\frac{\text { Profit aftertax }}{\text { Owners'equity }} * 100 \%
$$

Accounts receivable turnover ratio $=$ The current period net sales Early accounts receivable balance + The end of the accounts receivable balance

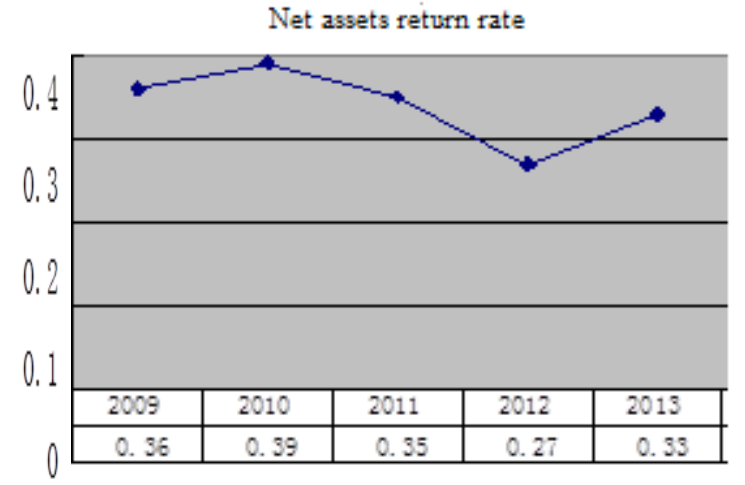

Figure 4 2009-2013 Guizhou Mao-tai ROE trend

Can be seen from Figure 4, since 10 years, ROE Mao-tai Group 12 years ago are in decline, down to 0.27 from 0.39 , a decrease reached nearly $30 \%$. But in 2013 they get picked, this result is due to the impact of policy and operational direction Mao-tai factory itself changes. From 2010 to 2012 ROE declining trend, mainly because of changes in the capital structure of the cause, but the following year the Mao-tai Group adopted structural adjustment, and secondly because the income tax rates and other aspects of adjustment also makes gains there has been an upward trend rate.

Mao-tai profitability generally on the rise, wine class manufacturing interest itself too, in addition to the class Mao-tai liquor industry leader, leadership worthy of the most cutting-edge. But in recent years to ban liquor, Mao-tai has also been prepared to allow guard hardship meaning, so the liquor industry a new pattern may occur in the future, according to the financial analysis Mao-tai to adjust its development model, so that a state-owned best.

\section{ANALYSIS OF OPERATING CAPACITY}

Enterprises operating capacity is in the operating state of the business turnover during the funds it generates for the efficiency and effectiveness be evaluated, this process requires the calculation and analysis, and then you can know the situation of the enterprise in the operation and management. Analysis out of the results can be better reflected in the degree of liquidity, the proof of utilization of funds of enterprises, as well as management level, these three are directly proportional to [6,7]. Indicators of this are accounts receivable turnover; inventory turnover and total asset turnover, etc., see equation (10) - (12). 
Inventory turnover $=\frac{\text { Sales cost }}{\text { The averagebalance of inventories }}$
$=\frac{\text { Sales cost }}{\text { Earlyaccounts receivablebalance }+ \text { The end of the accounts receivable balance }}$

Total asset turnover $=\frac{\text { Sales revenue }}{\text { Total assets }}$

According to related literature, calculate the 2009--2013 operational capacity in Guizhou Maotai index results in Table 4.

TABLE IV. Moutai nearly five years operating capacity table

Unit $(\%)$

\begin{tabular}{|l|l|l|l|l|l|}
\hline & $\mathbf{2 0 0 9}$ & $\mathbf{2 0 1 0}$ & $\mathbf{2 0 1 1}$ & $\mathbf{2 0 1 2}$ & $\mathbf{2 0 1 3}$ \\
\hline Accounts receivable turnover ratio & 88.12 & 126.14 & 202.92 & 344.06 & 377.71 \\
\hline Inventory turnover & 0.26 & 0.22 & 0.24 & 0.24 & 0.20 \\
\hline Total asset turnover & 0.54 & 0.51 & 0.61 & 0.66 & 0.62 \\
\hline
\end{tabular}

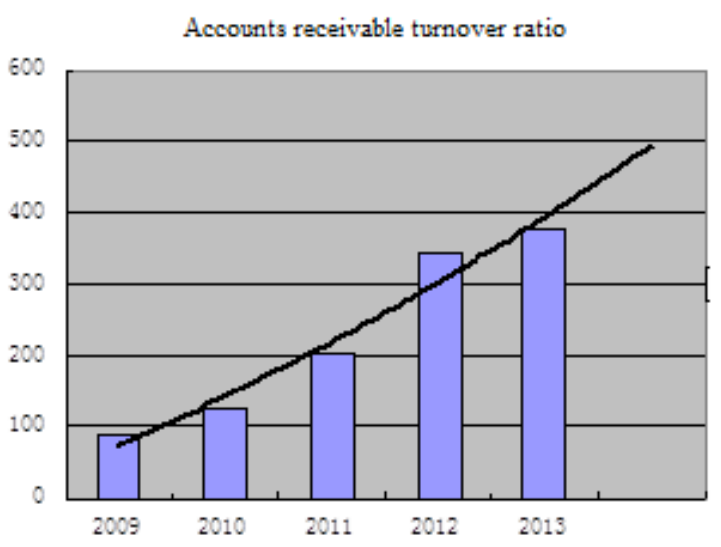

Figure 5 2009--2013 Guizhou Maotai accounts receivable turnover trend

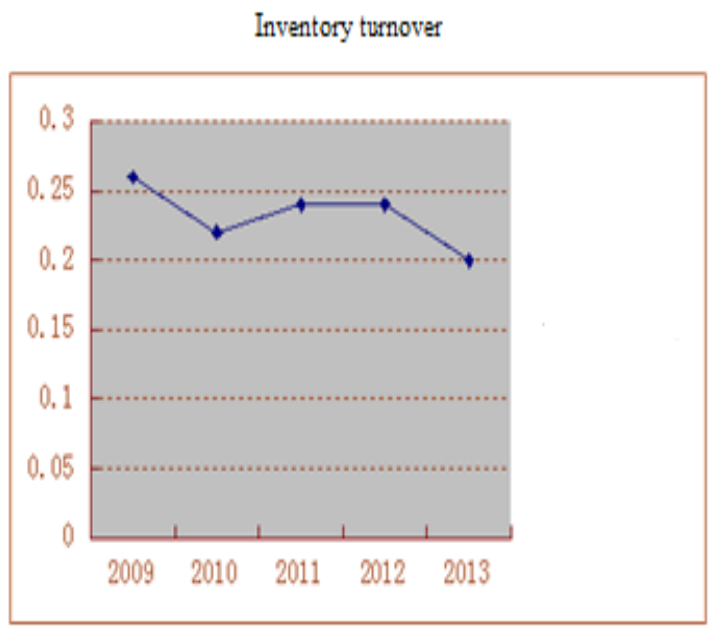

Figure 6 2010--2014 Guizhou Maotai accounts receivable turnover trend
As can be seen from Figures 5 and 6, compared to Mao-tai accounts receivable turnover increased, but inventory turnover showing an overall downward trend, especially from 2009 to 2010 , the decline is relatively large. The reason is certainly many, the biggest reason is that it is actually Mao-tai between sales and output is related. From the above data, the increase more slowly, indicates that the company's inventory turnover rate is relatively low. Mao-tai wine country's historic and cultural precipitation enjoyed a high reputation in marketing is to take rigorous evaluation select agent sales model, high recovery efficiency receivables. Mao-tai liquor and other high-end production of alcoholic products, finished generally cyclical in five years or more, of course, we all vintages longer worth its value is higher, natural inventory turnover rate is relatively low. For example, flying Mao-tai series, in 2009, production was 23,000 tons in 2013 , the annual output to 52,500 tons already, five years to the world. This growth rate is quite fast. But Mao-tai to go through 5 years to put on the market, so even yield rapid, but the market did not put the amount of formation of the corresponding growth rate, on this phenomenon, including some other liquor Mao-tai Group will also appear in the manufacturing, output growth in every year, it will cause its inventory turnover rate in a downward trend. 


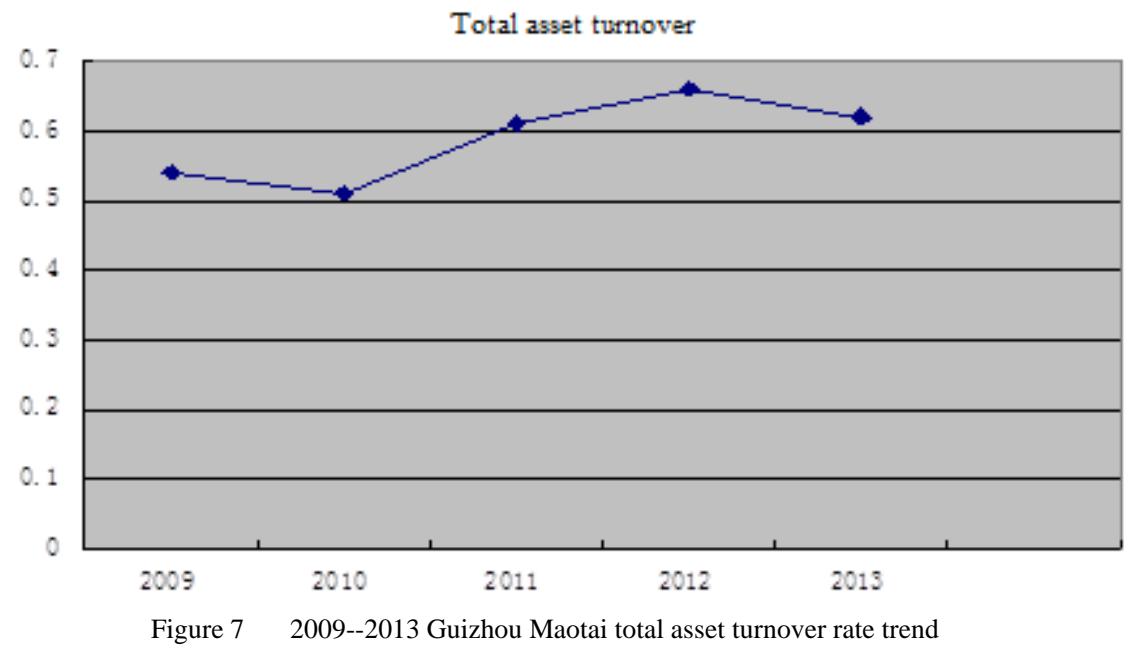

The total asset turnover index is high, indicating that the total asset turnover speed. Seen from Fig. 7, 2009 from 2 years to 10 years, with a total turnover of magnitude is relatively stable, dropping by less than $10 \%$, but the total turnover rose between 2010 to 2012 declined from 0.51 It increased to 0.66 , an increase of $29.4 \%$, followed by one year and down 0.04 percentage points, indicating that the Maotai sales this has done is good, and its sales are strong. While between 12 years and 13 years have decreased, but did not significantly affect the speed Maotai asset turnover was due to the implementation of the new policy caused. So ROE previous mentioned reasons will decline in total asset turnover has increased. Later we can know by Du Pont analysis system, each financial index analysis or the industry in terms of financial indicators and the level of the enterprise at every level can be evaluated by the gradual decomposition financial position and operating results of this business, this is a relatively easy to achieve this purpose.

\section{CONCLUSION}

Financial statement analysis based on financial indicators as reflected in corporate financial reporting as the main basis for the internal problems and reflect the financial position and operating results of the analysis, and then the process of enterprise operating profit to be understood, to understand the business in operation the process of the emergence of adverse and fortune, future business development model, not only for financial activities summary, but also to predict the future financial situation. Financial management plays a connecting role, financial statement analysis in this cycle also served as a force not to be underestimated. In this paper, Guizhou Maotai Group from 2009 to 2013 five-year financial statements, based on comparison of the indicators reflected emphatically analyzes the enterprises operating in the process of assets and liabilities, solvency, operating capacity, profitability and growth capacity analysis to managers and other stakeholders deeper to understand the financial position and operating results of operations and financial condition of the relevant factors and the results obtained by the analysis carried out, and to distinguish the economic responsibility, clearly to the operator and service work objectively evaluate the performance of corporate officers and know the work, you can penalties and rewards, to enable operators to continue to improve their work, so you can make the right business decisions.

\section{ACKNOWLEDGEMENT}

This research was financially supported by Regional Science Fund of National Natural Science Foundation of China (Project approval number: 41261094).

\section{REFERENCES}

[1] Wang Wen. "Mao-tai Analysis of Financial Statements", Modern Economic Information, vol. 20, pp. 262-263, 2014.

[2] Liu Jun. "Mao-tai Analysis of Financial Statements", Business, pp.47-48, Apr. 2014.

[3] Wang Meng. "Listed company's financial competitiveness Comprehensive Analysis and Evaluation”, Beijing University of Posts and Telecommunications, 2012.

[4] Xue Gui. "Moutai core competitive analysis", Finance and Accounting, pp. 42-44, Nov. 2009.

[5] Gao Ang. "Moutai financial policy analysis", Capital University of Economics, 2014.

[6] Jiang Nan. "Accounting Moutai financial situation analysis", Financial Times, pp. 287-28, Aug. 2011.

[7] Deng Yulong, LIU view, "Moutai value investment based on analysis of the financial reporting framework analysis", Commercial Accounting, vol.16, pp.93-97, 2013.

[8] Chen Ping Qin, "Financial Analysis earnings quality analysis", Modern Business, vol.32, pp.235-236, 2010.

[9] Tang Xiaojuan, "Financial Analysis Social Responsibility introduced Thinking", Chinese.

[10] Liu Ying, "Financial Management Financial Analysis", China New Technologies and Products, vol.23 , pp.213-213, 2010. 